\title{
Integrated Model of Character Education Development Based on Moral Integrative to Prevent Character Value Breaches
}

\author{
Rahmat Nur 1, Suardi 2, Nursalam 3, Hasnah Kanji 4 \\ DOI: $10.35445 /$ alishlah.v13i1.272
}

\begin{abstract}
Info Artikel
Abstract

Keywords:

Moral Integrative

Character Education

Violation of Character

Values

Students

This research aims to produce a model of strengthening character education in university. This study's substance problem is students' bad behavior, so it requires a more comprehensive model of supporting character education. The research used a mix-method. It is a combination of qualitative methods and quantitative methods. The qualitative research instrument uses the researcher himself as the main instrument, while the quantitative tool uses a validated questionnaire. Qualitative research uses purposive sampling and random sampling techniques for quantitative research data collection techniques using interviews, observation, questionnaires, and documentation. The qualitative data analysis stages were carried out by starting to reduce data, display data, and verify data. The research results on the integration model of character education development developed at the University of Muhammadiyah Makassar are integrated with moral integrations, namely knowing, feeling, sinverbal, action, habitus, and culture (KFSAHC) to prevent violations of character values.
\end{abstract}

Kata kunci:

Integratif Moral

Pendidikan Karakter

Pelanggaran Nilai

Karakter

Mahasiswa

\begin{abstract}
Abstrak
Tujuan penelitian ini adalah untuk menghasilkan model penguatan pendidikan karakter di perguruan tinggi. Masalah substansi pada penelitian ini adalah buruknya perilaku mahasiswa, sehingga membutuhkan suatu model penguatan pendidikan karakter yang lebih komprehensif. Penelitian menggunakan mixmethod yaitu metode kombinasi metode kualitatif dan metode kuantitatif. Instrumen penelitian kualitatif menggunakan peneliti sendiri sebagai instrumen utama sedangkan instrumen kuantitatif menggunakan angket, yang sudah divalidasi. Penelitian kualitatif menggunakan purposive sampling dan teknik random sampling untuk penelitian kuantitatif. Teknik pengumpulan data menggunakan wawancara, observasi, angket dan dokumentasi. Tahapan analisis data kualitatif dilakukan mulai mereduksi data, mendisplay data, dan melakukan verifikasi data. Hasil penelitian model integrasi pengembangan
\end{abstract}

\footnotetext{
${ }^{1}$ Universitas Lambung Mangkurat, Kota Banjarmasin , Indonesia Email: rahmat.nur@ulm.ac.id

${ }^{2}$ Universitas Muhammadiyah Makassar, Kota Makassar, Indonesia Email: suardi@unismuh.ac.id

${ }^{2}$ Universitas Muhammadiyah Makassar, Kota Makassar, Indonesia

Email: suardi@unismuh.ac.id

3 Universitas Muhammadiyah Makassar, Kota Makassar, Indonesia

Email: nursalam.h@unismuh.ac.id

4 Universitas Muhammadiyah Makassar, Kota Makassar, Indonesia

Email: hasnahk10071987@gmail.com

Vol.13 (1) June, 2021

Received: November 19, 2020; Received in revised form: January 13, 2021; Accepted: January 21, 2021; Available online: March 30 , 2021

This is an open access article under a Creative Commons Attribution-NonCommercial-ShareAlike 4.0 International License
} 
pendidikan karakter yang telah dikembangkan di Universitas Muhammadiyah Makassar terintegrasi dengan integratif moral yaitu knowing, feeling, sinverbal, action, habitus dan culture (KFSAHC) untuk mencegah pelanggaran nilai-nilai karakter.

\section{PENDAHULUAN}

Integrasi pengembangan karakter bukan hanya pada jenjang pendidikan sekolah (Nursalam et al., 2020) (Kanji et al., 2020a) namun juga pada jenjang perguruan tinggi sangat penting untuk mahasiswa sebagai bentuk penguatan pendidikan karakter (Tambingon et al., 2018) (Suardi, Nursalam, et al., 2020) yang dapat diintegrasikan dengan tridharma perguruan tinggi (Eva, 2015) maupun catur dharma perguruan tinggi berbasis karakter. Pengembangan karakter mahasiswa sesuai dengan Kementerian Pendidikan dan Kebudayaan telah merancang penerapan pengembangan pendidikan karakter untuk semua jenjang pendidikan di Indonesia. Konfigurasi karakter dikembangkan berdasarkan olah pikir, hati, raga dan rasa/karsa (Zuchdi et al., 2010). Kebijakan nasional pembangunan karakter bangsa untuk mewujudkan penanaman nilai Pancasila, dan mencegah pergeseran nilai bangsa (Alawiyah, 2012). Revolusi mental atau karakter bangsa sebagai program strategis dalam bidang pendidikan di perguruan tinggi yang sesuai kebudayaan bangsa (Ta'dib, 2016)

Di dalam Renstra Universitas Muhammadiyah Makassar BAB III tentang kebijakan dan program strategis, salah satu strategi dasarnya adalah peningkatan akhlakul karimah atau karakter melalui dinamika kehidupan kampus yang islami di Universitas Muhammadiyah Makassar, bukan hanya berfokus pada aspek kognitif atau pengetahuan dan aspek psikomotorik atau keterampilan (Kanji et al., 2018) (Suardi \& Kanji, 2018, Suardi, 2017), yang dikembangkan melalui proses pembelajaran (Suardi \& Nursalam, 2020, Suardi \& Syarifuddin, 2018).

Kemudian dituangkan dalam strategi program sampai tahun 2020 yaitu memperkuat karakter melalui proses pendidikan nilai moral islam dan Kemuhammadiyahan (Renstra Unismuh, 2018). Pengembangan pendidikan karakter dilakukan melalui integrasi karakter dalam perencanaan, pelaksanaan dan evaluasi proses pembelajaran atau perkuliahan (Kanji et al., 2019a, Nursalam et al., 2020, Suardi \& Kanji, 2018), yang membutuhkan dukungan internal dan eksternal kampus (Kanji et al., 2020b), yang bersifat kolaboratif (Suardi, Agustang, et al., 2020). Semua itu dilakukan agar mahasiswa memiliki nilai-nilai karakter bangsa dan nilai-nilai Islami.

Kajian tentang buruknya perilaku mahasiswa seperti perilaku seks pranikah (Irmawaty, 2013), gaya hidup hedonisme (Tambingon et al., 2018), konflik mahasiswa (Asrul et al., 2019), demonstrasi anarkis (Muhajir \& Susanti, 2018), merokok di dalam kampus (Suardi \& Syarifuddin, 2018), menggunakan narkoba (Nurlaelah et al., 2019), mencontek saat ujian (Suardi \& Syarifuddin, 2018), hamil di luar nikah (Alavi et al., 2012), mencuri Motor (Nurkadri, 2017), minum minuman keras (Arnoldus et al., 2017), membuang sampah sembarangan (Aprinta et al., 2017). Sedangkan berdasarkan hasil pengamatan yang dilakukan sejak tahun 2018-2019 di kampus Universitas Muhammadiyah di berbagai Fakultas dan Program Studi, data wawancara dan dokumentasi awal dari beberapa dosen diperoleh data mayoritas mahasiswa yang mengalami demoralisasi nilai karakter, seperti bentrokan antar mahasiswa, hamil diluar nikah, pencurian motor, pengedaran dan penyalahgunaan narkoba, minum minuman keras, membuang sampah sembarangan dan merokok di dalam kampus.

Fenomena di atas menunjukkan pendidikan karakter di kampus Islami Universitas Muhammadiyah Makassar belum berjalan secara efektif sehingga penguatan nilai karakter perlu ditingkatkan di lingkungan Universitas Muhammadiyah Makassar. Model penanaman nilai karakter selama ini yang digunakan hanya sebatas mahasiswa memiliki pengetahuan karakter (knowing), perasaan karakter (feeling) dan perilaku berkarakter (action) (Lickona, 1991), namun belum menyentuh moral sinverbal, habitus dan culture pada level individu atau mahasiswa dan level kelompok atau Universitas. Hal tersebut bisa dikembangkan dalam aktivitas akademika di 
perguruan tinggi di Universitas Muhammadiyah Makassar sehingga pendidikan karakter bukan hanya dilakukan oleh individu saja namun secara kolektif oleh semua civitas akademika Universitas Muhammadiyah Makassar, pembentukan pribadi yang memiliki karakter positif (Nur et al., 2019). Pengembangan pendidikan karakter sangat penting dilakukan yang berbasis integratif moral (KFSAHC) di perguruan tinggi khusus di Universitas Muhammadiyah Makassar.

Penelitian tentang model pengembangan pendidikan karakter untuk siswa dan mahasiswa telah dilakukan oleh beberapa peneliti, seperti (Nasrudin et al., 2015) tentang model pengembangan pendidikan karakter berbasis fitrah manusia yaitu kesucian jiwa manusia. Namun kesucian jiwa itu sama halnya dengan moral feeling belum menjelaskan knowing, sinverbal, action, habitus, culture. (Rachman et al., 2017) tentang model pengembangan pendidikan karakter berbasis pelatihan, namun pelatihan hanya lebih berfokus pada moral action namun belum sampai pada moral knowing, feeling, sinverbal, habitus, culture. (Lexi, 2015) meneliti model pengembangan pendidikan karakter berbasis nilai sosial-kultural, namun nilai sosial kultural itu hanya berada pada moral habitus dan moral culture, belum menyentuh moral knowing, feeling, sinverbal, action. (Zuchdi et al., 2010) dan (Suardi et al., 2019) meneliti model pengembangan pendidikan karakter terintegrasi pada proses pembelajaran, namun integrasi karakter dengan pembelajaran bidang studi lebih berfokus pada aspek eksternal individu atau kelompok belum menjelaskan aspek individu ke kelompok (eksternal). (Walid, 2011) tentang model pengembangan pendidikan karakter berbasis ulul albab yaitu program pendidikan perpaduan pesantren perguruan tinggi, namun belum lebih berfokus pada aspek eksternal individu atau kelompok belum menjelaskan aspek individu ke kelompok (eksternal). Secara umum semua hasil penelitian belum mengkaji secara substansi tentang moral knowing, feeling, sinverbal, habitus dan culture. Sedangkan penelitian yang akan dilakukan berfokus pada model pengembangan pendidikan karakter yang terintegrasi moral knowing, feeling, sinverbal, habitus dan culture. Model pengembangan pendidikan karakter ini sangat penting karena menjelaskan model pengembangan pendidikan karakter mulai dari level individu sampai pada level kelompok atau komunitas, yang sangat berbeda dengan model pendidikan karakter sebelumnya yang hanya berfokus pada level individu atau level kelompok namun tidak pernah mengintegrasikannya.

\section{METODE}

Penelitian ini menggunakan metode mix-method concurrent embedded yaitu metode kombinasi metode kualitatif dan metode kuantitatif. Prosedur penelitian dengan menyatukan data kualitatif dan kuantitatif guna memperoleh data hasil analisis yang lebih komprehensif berdasarkan masalah (Creswell, 2013). Alasan menggunakan metode mix-method concurrent embedded rumusan masalah pada penelitian berbeda, menggunakan beberapa metode yang berbeda, menyeimbangkan data wawancara mendalam, data observasi dan data dokumen yang diperoleh dengan data hasil angket, melengkapi data kualitatif dengan data kuantitatif agar hasil penelitian lebih komprehensif, mengkonfirmasi informasi hasil data kualitatif dengan data kuantitatif agar hasil penelitian lebih valid (Sugiyono, 2011). Instrumen penelitian kualitatif menggunakan peneliti sendiri sebagai instrumen utama yaitu sebagai pengamat dan peneliti dan menggunakan instrumen lembar pedoman wawancara, lembar pedoman observasi, lembar pedoman catatan dokumentasi, kamera untuk foto atau video dan menggunakan alat perekam. Sedangkan instrumen kuantitatif menggunakan angket, yang sudah divalidasi informan penelitian. Penelitian kualitatif menggunakan purposive sampling (kualitatif) sedangkan penentuan sampel penelitian menggunakan teknik proportional stratified sampling. Peneliti menggunakan data hasil wawancara, data hasil angket maupun data hasil observasi sebagai data primer, sedangkan data dokumen dijadikan sebagai data sekunder terkait dengan penelitian. Pengumpulan data menggunakan (1) angket melalui penyebaran angket kepada semua responden, (2) observasi melalui pengamatan berjarak, pengamatan terbatas, dan pengamatan penuh, (3) wawancara mendalam melalui wawancara terpimpin yang disusun 
sebelumnya oleh peneliti berdasarkan rumusan masalah penelitian (4) dokumentasi melalui penelusuran dokumen yang terkait dengan penelitian seperti foto, aturan dan kebijakan. Peneliti melakukan analisis data yaitu reduksi data pada tahap pertama, melakukan display data pada tahap kedua dan melakukan verifikasi data pada tahap ketiga (Sugiyono, 2011), selanjutnya melakukan analisis data kuantitatif dengan melakukan uji ketepatan angket yang digunakan (reliabilitas) dan melakukan uji kebenaran angket yang digunakan (valid).

\section{HASIL PENELITIAN DAN PEMBAHASAN}

Nilai karakter yang dikembangkan kepada mahasiswa untuk mengatasi pelanggaran nilai karakter atau penyimpangan sosial (Suardi et al., 2018) yang dilakukan mahasiswa adalah seks setelah menikah, bukan Perilaku seks pranikah (Irmawaty, 2013), gaya hidup asketisme, bukan gaya hidup hedonisme (Tambingon et al., 2018), hidup damai, bukan konflik mahasiswa (Asrul et al., 2019), demo yang damai, bukan demonstrasi anarkis (Muhajir \& Susanti, 2018), tidak merokok di dalam kampus, bukan merokok di dalam kampus (Suardi \& Syarifuddin, 2018), tidak menggunakan narkoba, bukan menggunakan narkoba (Nurlaelah et al., 2019), bekerja sesuai kemampuan, bukan mencontek (Suardi \& Syarifuddin, 2018), menjaga keperawanan, bukan hamil di luar nikah (Alavi et al., 2012), mengambil hak sendiri, bukan mencuri motor (Nurkadri, 2017), minuman yang halal, bukan minum minuman keras (Arnoldus et al., 2017), membuang sampah pada tempatnya, bukan membuang sampah sembarangan (Aprinta et al., 2017), shalat berjamaah, bukan tidak melaksana kan shalat.

Pengembangan pengetahuan moral berdasarkan hasil penelitian mahasiswa Universitas Muhammadiyah Makassar memiliki pengetahuan moral terhadap berbagai nilai karakter yang perna dilakukan oleh mahasiswa, dan mengetahui pelanggaran nilai karakter yang dilakukan, meskipun tidak semua tingkatan moral knowing diketahui oleh mahasiswa terutama pada pengetahuan pribadi. Berikut tabel persentase mahasiswa yang memiliki moral knowing dari 50 responden terdiri dari mahasiswa.

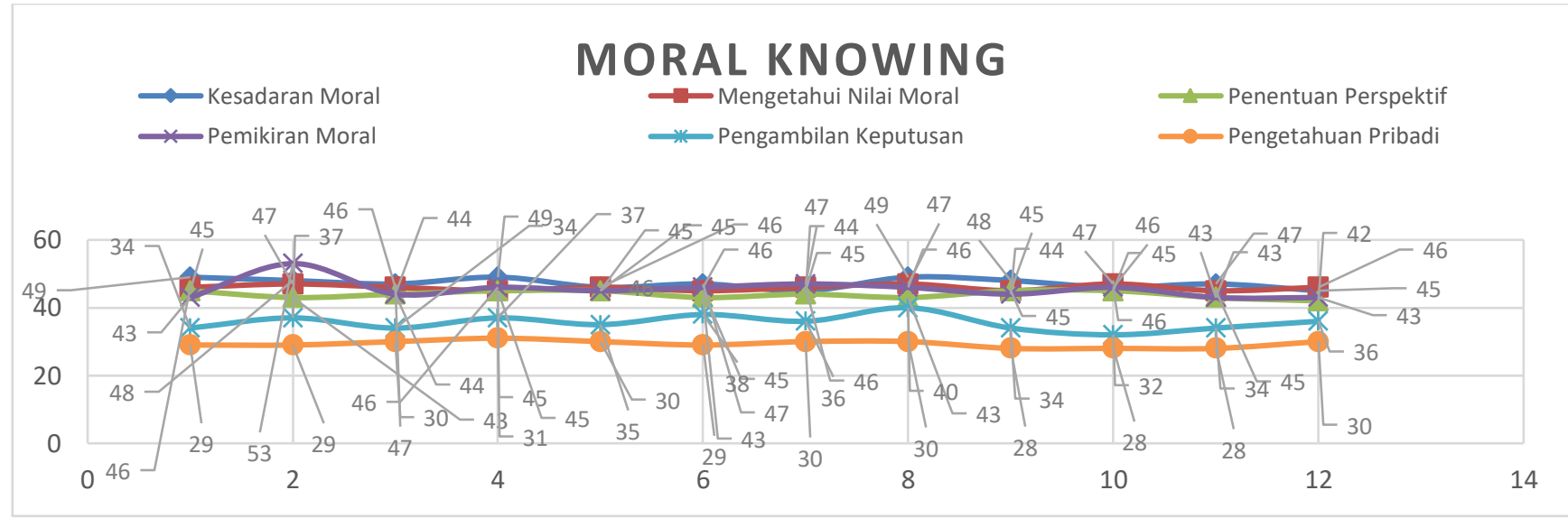

\section{Diagram 1. Moral knowing mahasiswa terhadap pelanggaran nilai-nilai karakter}

Pengembangan perasaan moral berdasarkan hasil penelitian mahasiswa Universitas Muhammadiyah Makassar memiliki perasaan moral terhadap berbagai nilai karakter yang pernah dilakukan oleh mahasiswa, dan menghindari pelanggaran nilai karakter meskipun tidak semua tingkatan moral feeling dirasakan oleh mahasiswa terutama pada kemampuan mengendalikan emosi yang berlebihan. Berikut tabel persentase mahasiswa yang memiliki moral feeling dari $5^{0}$ responden terdiri dari mahasiswa dan dosen. 


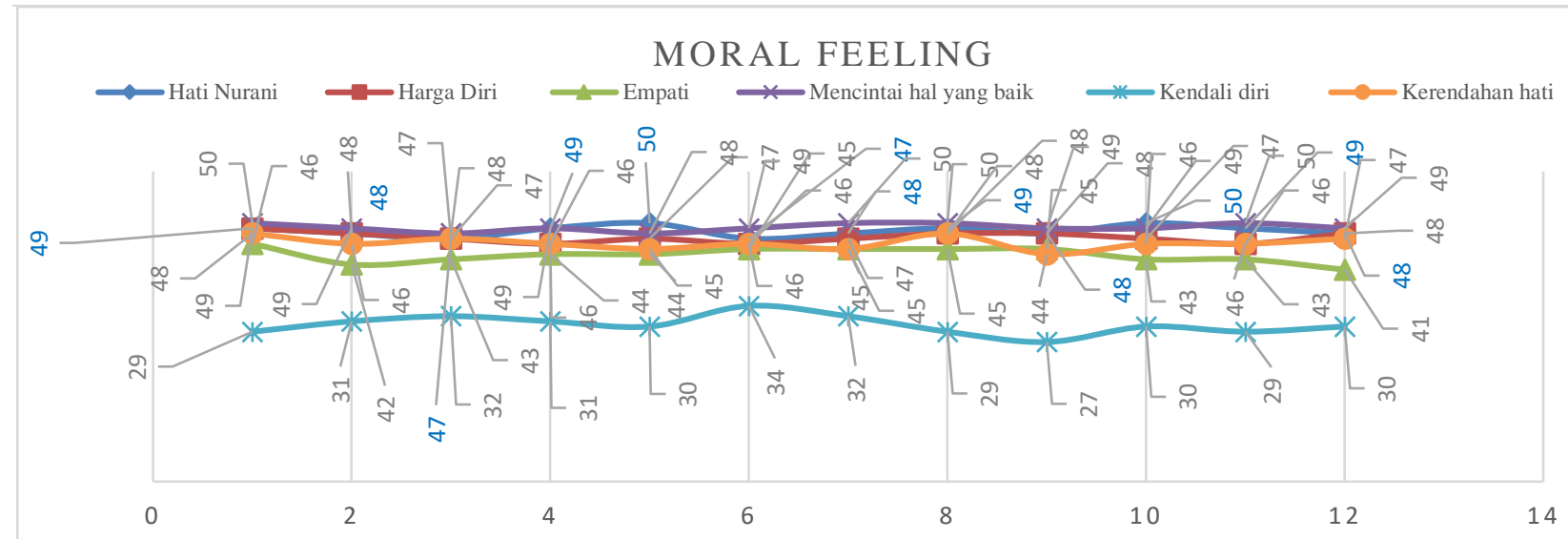

Diagram 2. Moral feeling mahasiswa dalam proses perkuliahan

Pengembangan simbol dan kata moral berdasarkan hasil penelitian mahasiswa Universitas Muhammadiyah Makassar memiliki simbol dan kata-kata moral terhadap berbagai nilai karakter yang perna dilakukan oleh mahasiswa, dan menghindari pelanggaran nilai karakter meskipun tidak semua tingkatan moral feeling dirasakan oleh mahasiswa terutama pada kemampuan melakukan perbaikan (revisi) terhadap berbagai kata dan simbol-simbol moral. Berikut tabel persentase mahasiswa yang memiliki moral sinverbal dari 50 responden terdiri dari mahasiswa dan dosen.

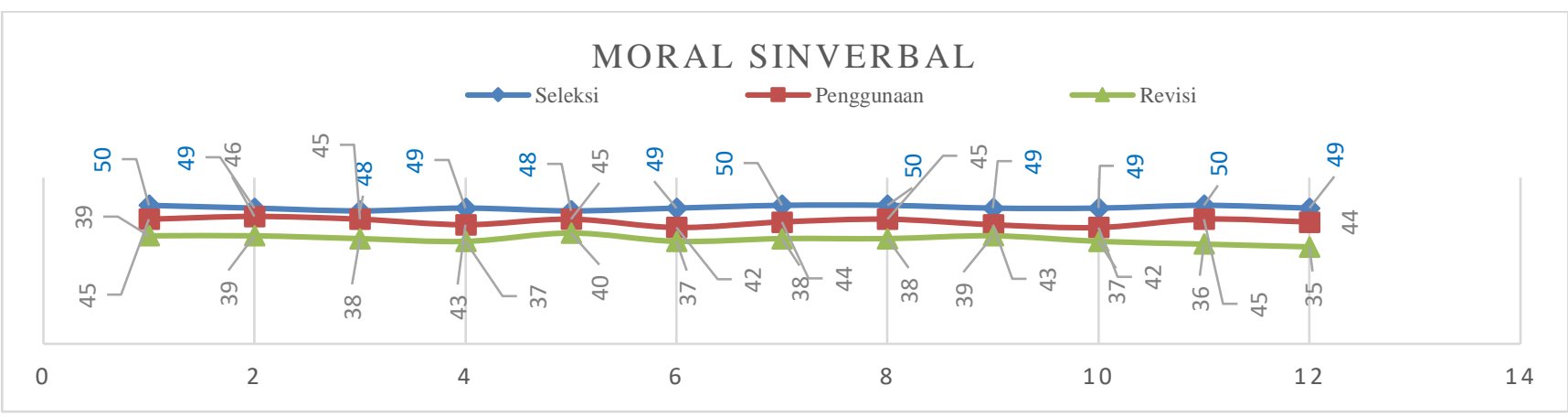

Diagram 3. Moral sinverbal mahasiswa dalam proses perkuliahan

Pengembangan perilaku moral berdasarkan hasil penelitian mahasiswa Universitas Muhammadiyah Makassar memiliki tindakan moral terhadap berbagai nilai karakter yang perna dilakukan oleh mahasiswa, dan menghindari pelanggaran nilai karakter meskipun tidak semua tingkatan moral action dilakukan oleh mahasiswa terutama pada kemampuan memecahkan berbagai persoalan yang dihadapi secara adil. Berikut tabel persentase mahasiswa yang memiliki moral action dari 50 responden terdiri dari mahasiswa dan dosen.

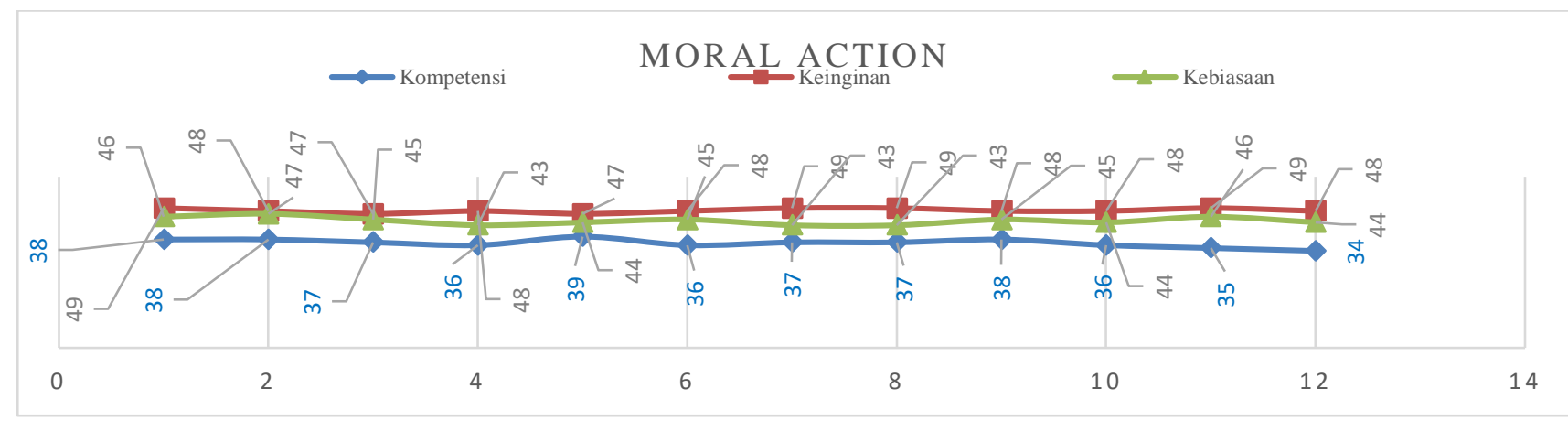

Diagram 4. Moral action mahasiswa dalam proses perkuliahan 
Pengembangan kebiasaan moral berdasarkan hasil penelitian mahasiswa Universitas Muhammadiyah Makassar memiliki kebiasaan moral terhadap berbagai nilai karakter yang perna dilakukan oleh mahasiswa dan menghindari pelanggaran nilai karakter meskipun mahasiswa belum maksimal pada penerimaan habitus dan habitus kolektif. Berikut tabel persentase mahasiswa yang memiliki moral habitus dari 50 responden terdiri dari mahasiswa.

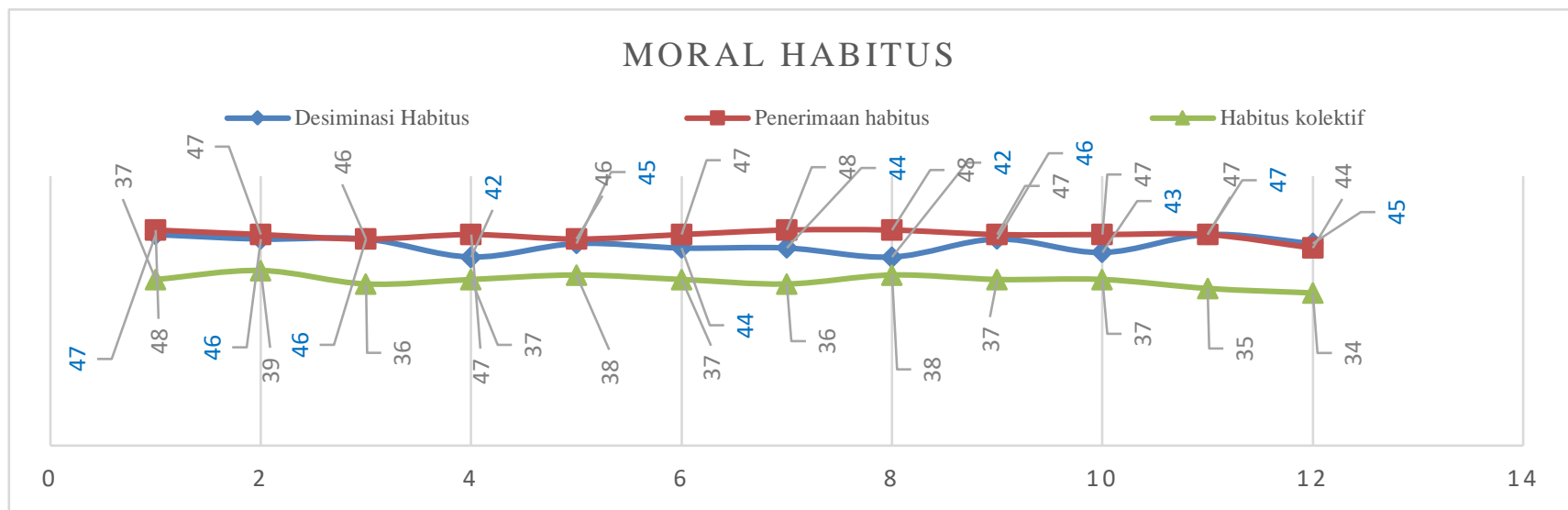

Diagram 5. Moral habitus mahasiswa dalam proses perkuliahan

Pengembangan budaya moral berdasarkan hasil penelitian mahasiswa Universitas Muhammadiyah Makassar masih kurang memiliki budaya moral terhadap berbagai nilai karakter yang harus dilakukan oleh mahasiswa dan menghindari pelanggaran nilai karakter. Meskipun mahasiswa dan civitas akademika belum maksimal mencapai sistem moral kultural, norma kultural dan peradaban. Berikut tabel persentase mahasiswa yang memiliki moral culture dari 50 responden terdiri dari mahasiswa.

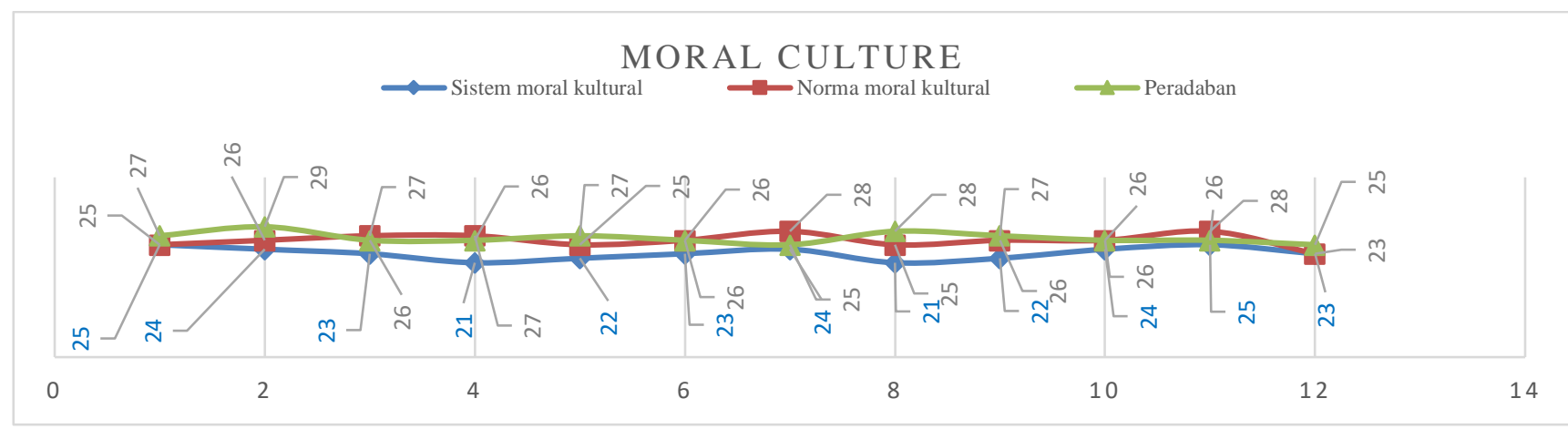

Diagram 6. Moral culture mahasiswa dalam proses perkuliahan

Model pengembangan pendidikan karakter di Universitas Muhammadiyah Makassar merujuk dari model pendidikan karakter oleh (Lickona, 1991) tentang moral knowing, moral feeling dan moral action pada level mikro (individu). Namun pendidikan karakter bukan hanya terkait dengan individu namun juga terkait dengan kelompok sosial dan masyarakat luas (makro), sehingga pengembangan pendidikan karakter harusnya gabungan moral knowing, feeling, sinverbal, action, habitus, culture (KFSAHC) sebagai integratif moral pada level mikro (individu) sampai pada level makro (kelompok masyarakat) sebagai suatu kesatuan yang komprehensif.

Tingkatan pertama model pengembangan pendidikan karakter yang dikembangkan di Universitas Muhammadiyah Makassar untuk menanamkan nilai-nilai karakter dan mencegah pelanggaran nilai karakter yaitu moral knowing yang terbagi enam tingkatan moral yaitu mahasiswa mengetahui mana yang baik dan buruk, mahasiswa mengetahui cara melakukan hal yang benar atau baik dan menghindari hal yang salah atau buruk, mahasiswa mampu melihat sesuatu dari cara pandang orang lain terhadap hal yang baik dan buruk, mahasiswa mengetahui mengapa setiap manusia harus bermoral, mahasiswa mampu mengambil keputusan terhadap permasalahan yang 
dihadapi. mahasiswa mengetahui hal buruk dan baik yang ada dalam dirinya. Moral knowing mengajarkan pengetahuan baik/ positif / bermoral atau berkarakter untuk mahasiswa (Kanji et al., 2019b). Moral knowing diperlukan agar setiap individu atau mahasiswa dapat menyesuaikan diri dengan kaidah atau aturan yang berlaku di Perguruan Tinggi atau masyarakat (Dyah, 2014), sangat penting diajarkan ke peserta didik atau mahasiswa (Setiawan, 2013), namun pengetahuan moral tidak cukup untuk mahasiswa, karena mahasiswa masih perlu untuk memiliki moral feeling atau perasaan moral (Setiawan, 2013).

Tingkatan kedua model pengembangan pendidikan karakter yaitu moral feeling yang terbagi enam tingkatan moral yaitu mahasiswa merasa memiliki kewajiban melakukan hal yang benar atau baik dan menghindari hal yang salah atau buruk, mahasiswa mempertahankan hal yang dianggap baik, mahasiswa mampu merasakan apa yang dirasakan orang lain, mahasiswa tertarik pada hal-hal yang baik, mahasiswa mampu mengendalikan emosi yang berlebihan, mahasiswa terbuka terhadap suatu kebenaran dan mau memperbaiki kesalahan. Moral feeling mengajarkan mahasiswa untuk memiliki perasaan yang baik/ positif / bermoral atau berkarakter (Kanji et al., 2019b). Moralfeeling merupakan bagian dan kelanjutan dari moral knowing (Dyah, 2014), secara sinergi berkontribusi pada pengembangan karakter mahasiswa (Setiawan, 2013).

Tingkatan yang ketiga model pengembangan pendidikan karakter yaitu moral sinverbal yang terbagi enam tingkatan moral yaitu mahasiswa mampu menyeleksi setiap kata dan simbol yang baik digunakan dalam berinteraksi, mahasiswa mampu menggunakan kata dan simbol yang baik, mahasiswa mampu memperbaiki kata dan simbol baik sesuai dengan lingkungannya. Moral sinverbal mengajarkan mahasiswa untuk memiliki kata-kata dan simbol-simbol yang baik/ positif / bermoral atau berkarakter (Kanji et al., 2019)

Tingkatan yang keempat model pengembangan pendidikan karakter yaitu moral action yang terbagi tiga tingkatan moral yaitu mahasiswa mampu memecahkan berbagai persoalan secara adil, mahasiswa selalu memiliki keinginan untuk melakukan hal yang benar atau baik dan menghindari hal salah atau buruk, mahasiswa melakukan hal yang baik secara berulang-ulang. Moral action mengajarkan mahasiswa untuk memiliki perilaku yang baik/ positif / bermoral atau berkarakter (Kanji et al., 2019). Moral action sebagai lanjutan moral knowing dan moral feeling (Dyah, 2014), secara sinergi juga berkontribusi pada pengembangan karakter mahasiswa (Setiawan, 2013).

Tingkatan yang lima model pengembangan pendidikan karakter yaitu moral habitus yang terbagi tiga tingkatan moral yaitu mahasiswa menyebarluaskan hal-hal yang baik kepada orang lain, mahasiswa menerima kebiasaan yang baik yang diperoleh dari interaksi dengan orang lain, mahasiswa melakukan hal yang baik sesuai dengan kebiasaan kelompok masyarakat. Moral habitus mengajarkan mahasiswa untuk memiliki kebiasaan yang baik/ positif / bermoral atau berkarakter (Kanji et al., 2019b). Moral habitus dimiliki mahasiswa jika mampu mengembangkan perilaku baik/ positif / bermoral atau berkarakter menjadi suatu kebiasaan (Ibda, 2012).

Tingkatan yang ke enam model pengembangan pendidikan karakter yaitu moral culture yang terbagi tiga tingkatan moral yaitu mahasiswa dan dosen secara kolektif melakukan hal-hal yang baik dalam kehidupan sosial dari segala aspek kehidupannya seperti agama, ekonomi dan politik, mahasiswa dan dosen menjadikan hal yang baik sebagai norma atau aturan yang memiliki sanksi bagi yang melanggar, mahasiswa dan dosen menjadikan hal yang baik sebagai identitas dan tolak ukur perilaku mahasiswa maupun dosen. Moral culture mengajarkan mahasiswa untuk memiliki budaya yang baik/ positif / bermoral atau berkarakter (Kanji et al., 2019b). Moral culture adalah akumulasi dari moral knowing, feeling, sinverbal, action, habitus menjadi suatu budaya, bukan hanya pada individu mahasiswa namun sampai pada kelompok atau civitas akademika Universitas Muhammadiyah Makassar. Integratif moral sebagai model pengembangan pendidikan karakter yang dikembangkan di Universitas Muhammadiyah Makassar selengkapnya dapat dilihat pada tabel berikut: 
Tabel 1. Integratif moral (knowing, feeling, sinverbal, action, habitus, dan culture (KFSAHC) pada level mikro/individu dan makro/kelompok)

\begin{tabular}{clc}
\hline No & \multicolumn{1}{c}{ Integratif Moral } & Tingkatan \\
\hline 1 & $\begin{array}{l}\text { Moral culture yaitu mahasiswa dan civitas akademika menjadikan } \\
\text { moralitas sebagai sistem nilai. }\end{array}$ & Makro (Kelompok) \\
2 & $\begin{array}{l}\text { Moral habitus yaitu mahasiswa dan civitas akademika memiliki } \\
\text { kebiasaan-kebiasaan moralitas. }\end{array}$ & Mikro (Individu) - Makro \\
3 & $\begin{array}{l}\text { Moral action yaitu mahasiswa berperilaku sesuai dengan moralitas. } \\
\text { (Kelompok) } \\
4\end{array}$ & $\begin{array}{l}\text { Moral sinverbal yaitu mahasiswa menggunakan simbol dan kata } \\
\text { moralitas }\end{array}$ \\
5 & Moral feeling yaitu mahasiswa memiliki perasaan moralitas \\
6 & Moral knowing yaitu mahasiswa memiliki pengetahuan moralitas & \\
\hline
\end{tabular}

Model pengembangan pendidikan karakter yang berbasis integrasi moral telah mencegah pelanggaran nilai-nilai karakter yang dilakukan oleh mahasiswa karena pengembangan pendidikan karakter bukan hanya pada tingkatan pengetahuan moral, perasaan moral, pengunaan kata dan simbol moral, tindakan moral, kebiasaan moral namun sampai pada budaya moral yang dilakukan oleh mahasiswa sebagai level mikro atau individu namun juga dilakukan oleh seluruh civitas akademika Universitas Muhammadiyah Makassar pada level makro.

\section{SIMPULAN}

Model pengembangan pendidikan karakter yang telah dikembangkan di Universitas Muhammadiyah Makassar terintegrasi dengan moral knowing, moral feeling, moral sinverbal, moral action, moral habitus dan moral culture (KFSAHC) sebagai suatu kesatuan yang integratif mulai pada level individu sampai pada level kelompok atau civitas akademika Universitas Muhammadiyah Makassar dalam menanamkan nilai-nilai karakter untuk mencegah pelanggaran nilai-nilai karakter.

\section{DAFTAR PUSTAKA}

Alavi, K., Nen, S., Ibrahim, F., Md, N. A., Suhaimi, M. M., \& Mohd, N. N. (2012). Hamil luar nikah dalam kalangan remaja. Journalarticle.Ukm.My, $7(1), \quad 131-140$. http://journalarticle.ukm.my/5013/1/khadijaho12(b).pdf

Alawiyah, F. (2012). Kebijakan dan Pengembangan Pembangunan Karakter melalui Pendidikan di Indonesia. Jurnal Inspirasi, $3(1), \quad$ 87-101. http://jurnal.dpr.go.id/index.php/aspirasi/article/view/259. https://doi.org/10.46807/aspirasi.v3i1.259

Aprinta, G. E. B., Syamsiah, S., \& L, H. (2017). Penerapan Strategi Marketing Sosial dalam Membentuk Kesadaran Mahasiswa. Jurnal The Messenger, 9(2), 241. https://doi.org/10.26623/themessenger.v9i2.516

Arnoldus, A. T., Puspitawati, T., \& Marlinawati, U. (2017). Fenomena Perilaku Mengkonsumsi Minuman Keras Mahasiswa Program Studi S-1 Kesehatan Masyarakat Universitas Respati Yogyakarta Consume Behavior Phenomenon Liquor Among Undergraduate Of Public Health Students University Of Respati Yogyakarta. Jurnal Formil (Forum Ilmiah) KesMas Respati, 2(1), 25-31. http://formilkesmas.respati.ac.id/index.php/formil/article/view/59

Asrul, A., Nurdin, \& Nur, S. (2019). Solidaritas Sosial Sepuluh Pilar UKM Universitas Muhammadiah Makassar. Equilibrium: Jurnal Pendidikan, $7(2), \quad 218-225$. https://jurnal.unismuh.ac.id/index.php/equilibrium/article/view/2658. https://doi.org/10.26618/equilibrium.v7i2.2658

Creswell, W. J. (2013). Research Design Pendekatan Kualitatif, Kuantitatif dan Mixed. Pustaka Pelajar.

Dyah, Y. K. (2014). Peran Guru Dalam Membentuk Karakter Kepemimpinan Pada Peserta Didik Di Sma Al Hikmah Surabaya. Jurnal Inspirasi Manajemen Pendidikan, 4(4), 190-200. https://jurnalmahasiswa.unesa.ac.id/index.php/inspirasi-manajemenpendidikan/article/view/7739 
Eva, M. M. R. (2015). Urgensi Pendidikan Karakter di Perguruan Tinggi. Jurnal Pendidikan IlmuIlmu Sosial , $7(1)$, https://jurnal.unimed.ac.id/2012/index.php/jupiis/article/view/2297. https://doi.org/10.24114/jupiis.v7i1.2297.g4484

Ibda, F. (2012). Pendidikan Moral Anak Melalui Pengajaran Bidang Studi Ppkn Dan Pendidikan Agama. Jurnal Ilmiah Didaktika, 12(2), 338-347. https://doi.org/10.22373/jid.v12i2.457

Irmawaty, L. (2013). Perilaku seksual pranikah pada mahasiswa. Jurnal Kesehatan Masyarakat, 9(1), 44-52. $\quad$ http://journal.unnes.ac.id/nju/index.php/kemas. https://doi.org/10.15294/kemas.v9i1.2829

Hasnah, K., Amin, B., Syakur, A., \& Suardi, S. (2018). Peningkatan Hasilbelajar Bahasa Indonesia Melalui Model Pembelajaran Kooperatif Tipe Numbered Heads Together. JRPD (Jurnal Riset Pendidikan Dasar), 1(1), 25-33. https://doi.org/10.26618/jrpd.v1i1.1236

Kanji, H., Nursalam, N., Nawir, M., \& Suardi, S. (2019). Evaluasi Integrasi Pendidikan Karakter dalam Pembelajaran Ilmu Pengetahuan Sosial di Sekolah Dasar. JED (Journal of Etika Demokrasi), 4(2). https://doi.org/10.26618/jed.v4i2.2386

Kanji, H., Nursalam, N., Nawir, M., \& Suardi, S. (2020). Integration of social care characters and moral integratif on social science lessons in elementary school. Al-ishlah: Jurnal Pendidikan, 12(2), 413-427. https://doi.org/10.35445/alishlah.v12i2.26o

Kanji, H., Nursalam, N., Nawir, M., \& Suardi, S. (2019). Model integrasi pendidikan karakter dalam pembelajaran ilmu pengetahuan sosial di sekolah dasar. Jurnal pendidikan dasar perkhasa: Jurnal Penelitian Pendidikan Dasar, 5(2), 104-115. https://doi.org/10.31932/jpdp.v5i2.458

Kanji, H., Nursalam, N., Nawir, M., \& Suardi, S. (2020). Supporting and Inhibiting Factors of Character Education in Learning Social Studies at Primary Schools. JED (Journal of Etika Demokrasi), 5(1), 1-14. https://doi.org/10.26618/jed.v5i1.2966

Lexi, A. Lo. (2015). Pengembangan model pendidikan karakter berbasis nilai sosio-kultural pada siswa SMA di Minahasa. Mimbar: Jurnal Sosial Dan Pembangunan, 31(2), 319-327. https://ejournal.unisba.ac.id/index.php/mimbar/article/download/1416/1112.

Lickona, T. (1991). Educating for Character: How Our Schools Can Teach Respect and Responsibility - Thomas Lickona - Google Buku. https://books.google.co.id/books?hl=id\&lr=\&id=QBIrPLf2siQC\&oi=fnd\&pg=PA2\&dq=licona +Character+can+refer+to:+(1)+Personality+traits+or+virtues+such+as+responsibility+and+ respect+for+others.+(2)+Emotions+such+as+guilt+or+sympathy+(3)+Social+skills+such+as +conflict+management+or+effective+communication+(4)+Behaviours+such+as+sharing+o\& ots=xdqpW8tBPX\&sig=KikJ51qzZVNYFBhMqpH-

OBxnZus\&redir_esc $=\mathrm{y} \# \mathrm{v}=$ onepage\&q\&f$=$ false

Muhajir, \& Susanti, D. (2018). Persepsi Masyarakat Terhadap Perilaku Demonstrasi Mahasiswa Universitas Muhammadiyah Makassar. JED (Jurnal Etika Demokrasi), 3(2), 95-100. https://doi.org/10.26618/jed.v3i2.1935. https://doi.org/10.26618/jed.v3i2.1935

Nasrudin, Herdiana, I., \& Nazudi, N. (2015). Pengembangan Model Pendidikan Karakter Berdasarkan Sifat Fitrah Manusia. Jurnal Pendidikan Karakter, o(3), 264-271. https://doi.org/10.21831/jpk.voi3.5631

Nur, A. H., Sopandi, W., \& Mustapha, I. (2019). Analisis pengembangan karakter, keterampilan proses sains, dan penguasaan konsep siswa pada topik koloid melalui pembelajaran inkuiri terbimbing. Edusains, 8(2), 157-165. https://doi.org/10.15408/es.v8i2.1849

Nurkadri, N. (2017). Persepsi Mahasiswa terhadap Fenomena Pencurian Kendaraan Roda Dua (Studi Kasus di Kampus II UIN Alauddin Makassar). Universitas islam negeri alauddin makassar.

Nurlaelah, N., Harakan, A., \& Mone, A. (2019). Strategi Badan Narkotika Nasional (BNN) Dalam Mencegah Peredaran Narkotika di Kota Makassar. Gorontalo Journal of Government and Political Studies, 2(1), 024. https://doi.org/10.32662/gjgops.v2i1.499

Nursalam, Nawir, M., Suardi, \& Kanji, H. (2020). Model Pendidikan Karakter Pada Mata Pelajaran Ilmu Pengetahuan Sosial Di Sekolah Dasar (Vol. 1). CV. AA. RIZKY. https://books.google.co.id/books?hl=id\&lr=\&id=8tUKEAAAQBAJ\&oi=fnd\&pg=PA63\&dq=b uku+suardi+nursalam+pendidikan+karakter\&ots=1A-g2fQs4\&sig=zVhj4kYePdGJVfogG4l9nxFs-H4\&redir_esc=y\#v=onepage\&q=buku suardi 
nursalam pendidikan karakter\&f=false

Rachman, M., Masrukhi, M., Munandar, A., \& Suhardiyanto, A. (2017). Pengembangan Model Manajemen Pelatihan Dan Pengembangan Pendidikan Karakter Berlokus Padepokan Karakter. Refleksi Edukatika: Jurnal Ilmiah Kependidikan, 8(1), 16-26. https://doi.org/10.24176/re.v8i1.1779

Setiawan, D. (2013). Peran pendidikan karakter dalam mengembangkan kecerdasan moral. Jurnal Pendidikan Karakter, 53-63. https://journal.uny.ac.id/index.php/jpka/article/view/1287. https://doi.org/10.21831/jpk.voi1.1287

Suardi, S. (2017). Peningkatan Hasil Belajar Sosiologi Pokok Bahasan Interaksi Sosial Melalui Metode Diskusi pada Siswa Kelas X MA. Muhammadiyah Panaikang Kacamatan Bissappu Kabupten Bantaeng. JED (Journal of Etika Demokrasi), 2(1). https://doi.org/10.26618/jed.v2i1.1145

Agustang, A., \& Sahabuddin, J. (2020, October). Model kolaborasi sosial pendidikan karakter di sekolah swasta kecamatan bissappu kabupaten bantaeng. In prosiding seminar dan diskusi pendidikan dasar.

Suardi, \& Nursalam. (2020). Penerapan Model Pembelajaran Saintifik Approach Berbasis Media Classroom | Indonesian Journal of Sociology, Education, and Development. Indonesian Journal of Sociology, Education, and Devolopment, 2(2), 88-97. http://ijsed.ap3si.org/index.php/journal/article/view/vol2iss2_2020_2suardi

Hasnah, K. (2020). Penguatan Pendidikan Karakter: Berbasis Integratif Moral Di Perguruan Tinggi (Vol. 1). CV. AA. RIZKY.

Suardi, S., Herdiansyah, H., Ramlan, H., \& Mutiara, I. A. (2019). Implementasi Pendidikan Karakter Melalui Mata Pelajaran Pendidikan Kewarganegaraan di SMA Jaya Negara Makassar. JED (Journal of Etika Demokrasi), 4(1). https://doi.org/10.26618/jed.v4i1.1983

Suardi, S., \& Kanji, H. (2018). Lecture Model of Student Transfer Discussion Method to Increase Student's Activeness and Learning Outcomes. Journal of Educational Science and Technology (EST), 4(1), 48-54. https://doi.org/10.26858/est.v4i1.4814

Suardi, S., Megawati, M., \& Kanji, H. (2018). Pendidikan Karakter di Sekolah (Studi Penyimpangan Siswa di Mts Muhammadiyah Tallo). JED (Journal of Etika Demokrasi), 3(1). https://doi.org/10.26618/jed.v3i1.1979

Suardi, S. (2018). Penerapan Model Pembelajaran Saintifik Approacd Berbasis Media Pembelajaran Kearifan Lokal pada Mata Kuliah Dasar-Dasar Sosiologi dalam Membangun Karakter dan Meningkatkan Hasil Belajar Mahasiswa Pendidikan Sosiologi Universitas Muhammadiyah Makassar. JED (Journal of Etika Demokrasi), 3(2). https://doi.org/10.26618/jed.v3i2.1627

Sugiyono. (2011). Metode penelitian kombinasi (mixed methods). Alfabeta.

Ta'dib, M. K. (2016). Telaah revolusi mental dan pendidikan karakter dalam pembentukkan sumber daya manusia indonesia yang pandai dan berakhlak mulia. Ta'dib, 18(1), 13-25. http://ecampus.iainbatusangkar.ac.id/ojs/index.php/takdib/article/view/274/o. http://dx.doi.org/10.31958/jt.v18i1.274

Tambingon, J., Tasik, F. C. M., \& Purwanto, A. (2018). Gaya Hidup Hedonisme Mahasiswa Fakultas Ekonomi dan Bisnis Universitas Sam Ratulangi di Kota Manado. Ejournal.Unsrat.Ac.Id, 1-8. https://ejournal.unsrat.ac.id/index.php/JAP/article/view/17062

Walid, M. (2011). Model Pendidikan Karakter Di Perguruan Tinggi Agama Islam (Studi tentang Pendidikan Karakter Berbasis Ulul albab di Universitas Islam Negeri Maulana Malik Ibrahim Malang). Jurnal EL-QUDWAH, $1(5) . \quad$ http://ejournal.uinmalang.ac.id/index.php/lemlit/article/view/1943

Zuchdi, D., Kun Prasetya, Z., \& Siasah, D. M. (2010). Pengembangan Model Pendidikan Karakter Terintegrasi Dalam Pembelajaran Bidang Studi Di Sekolah Dasar. In journal.uny.ac.id. https://journal.uny.ac.id/index.php/cp/article/download/224/143 